\title{
Chemical Quality of Culled Duck Meatball (Anasplathyryncos) Substituted with Edamame Flour (Glycine max (L) Merril) Filler
}

\author{
Prayitno AH, Rahman TH \\ Department of Animal Science, Politeknik Negeri Jember \\ Jl. Mastrip Po Box 164 Jember - Indonesia \\ E-mail: agushp@polije.ac.id
}

(received 30-05-2020; revised 03-07-2020; accepted 26-09-2020)

\begin{abstract}
ABSTRAK
Prayitno, AH and Rahman, TH. 2020. Kualitas kimia bakso daging itik afkir (Anasplathyryncos) yang disubstitusi filler tepung edamame (Glycine $\max (L)$ Merril). JITV 25(4): 190-194. DOI: http://dx.doi.org/10.14334/jitv.v25i4.2514

Penelitian ini bertujuan untuk mengetahui pengaruh subtitusi filler tepung edamame terhadap kualitas kimia bakso daging itik afkir. Materi penelitian terdiri dari daging itik afkir, tepung tapioka, tepung edamame, putih telur, bawang putih, bawang merah, garam, lada, monosodium glutamat, sodium tripolifosfat, dan es. Perlakuan substitusi filler tepung edamame yaitu P0 (0\%), P1 (5\%), P2 (10\%), P3 (15\%), dan P4 (20\%) dari total filler. Setiap perlakuan terdiri dari lima replikasi. Parameter yang diuji yaitu kadar air, protein, lemak, serat, dan abu. Data hasil uji kualitas kimia dianalisis dengan analisis variansi rancangan acak lengkap pola searah dan jika terdapat perbedaan yang signifikan $(\mathrm{P}<0,01)$ kemudian diuji lanjut dengan uji Duncan's New Multiple Range Test. Hasil penelitian menunjukan bahwa substitusi filler tepung edamame mulai dari level 5\% sudah sangat berpengaruh terhadap kadar air, protein, lemak, serat, dan abu bakso daging itik afkir. Tepung edamame dapat dijadikan sebagai substitusi filler sampai level $20 \%$ dengan memberi pengaruh baik terhadap peningkatan kandungan protein bakso, tetapi juga berdampak negatif dengan meningkatnya kandungan lemak bakso daging itik afkir.
\end{abstract}

Kata Kunci: Bakso, Daging Itik Afkir, Filler, Kualitas Kimia, Tepung Edamame

\begin{abstract}
Prayitno, AH and Rahman, TH. 2020. Chemical quality of culled duck meatball (Anas plathyryncos) substituted with edamame flour (Glycine max (L) Merril) filler. JITV 25(4): 190-194. DOI: http://dx.doi.org/10.14334/jitv.v25i4.2514

This study aimed to determine the effect of edamame flour filler substitution on the chemical quality of culled duck meatballs. The research material consisted of culled duck meat, tapioca flour, edamame flour, albumen, garlic, onion, salt, pepper, monosodium glutamate, sodium tripolyphosphate, and ice. The edamame flour filler substitution treatments were P0 (0\%), P1 (5\%), P2 (10\%), P3 (15\%), and P4 (20\%) from total filler. Each treatment consisted of five replications. The parameters which tested were moisture, protein, fat, fiber, and ash contents. Data on chemical quality results were analyzed by analysis of variance using completely randomized design and if there was significantly different $(\mathrm{P}<0.01)$, then it'll be further tested by the Duncan's New Multiple Range Test. Results showed that the substitution of edamame flour filler starting from the level of $5 \%$ was significantly affected water content, protein, fat, fiber, and ash of culled duck meatballs. Edamame flour can be used as a filler substitution up to $20 \%$ level by giving a good effect on increasing the meatball protein content, but also having a negative impact with increasing the fat content of culled duck meatballs.
\end{abstract}

Key Words: Meatball, Culled Duck Meat, Filler, Chemical Quality, Edamame Flour

\section{INTRODUCTION}

Ducks were one type of waterfowl that the meat was less desirable to the community because it has an offodor (Anggraini et al. 2017), rough textured and tough so low meat quality (Hafid et al. 2015; Smith et al. 2015). The volatile components derived from the oxidation of unsaturated fats were the cause of duck meat has an off-odor (Purba et al. 2010).This meat has a higher fat, protein content and lower calories rather than other poultry meats (Utami et al. 2011). The color of duck meat was darker than chicken meat (Huda et al. 2011). The chemical compositions of duck meat were
73.29-80.69\% moisture, $19.99-24.34 \%$ protein, $1.05-$ $1.18 \%$ ash (Qiao et al. 2017), $1.4 \%$ carbohydrate (Biswas et al. 2019), 1.55-2.30\% intramuscular fat (He et al. 2018), and 12.21-28.21\% fat (Lestari et al. 2015).

Quality of culled duck meat can be improved by processing as meatballs. Processing of duck meat into meatballs can reduce off-odor from duck meat (Anggraini et al. 2017). Duck meat processed into meatballs was preferred than other processed products (Putra et al. 2011; Kusmayadi \& Sundari 2019). The meatballs were one of the processed meat products made by grinding the meat, mixed with flour and spices, then formed into balls and boiled until cooked 
with hot water (Chakim et al. 2013). Meatballs are usually made from beef (Malini et al. 2016).

Increasing number of Indonesian population who are so busy resulted in the pattern of consumption of ready to cook meat and eat has developed so rapidly (Prayitno et al. 2019) one of which was meatballs, that have high acceptability and nutritional value (Prayitno et al. 2016; Prayitno et al. 2019). Chemical compositions of meatball consist of $8 \%$ minimum protein, $10 \%$ maximum fat, $70 \%$ maximum moisture, and 3\% maximum ash (SNI 2014). Meatballs can be produced using duck meat (Nurkhoeriyati et al. 2012; Murti et al. 2013; Haslia et al. 2015; Lestarini et al. 2015; Biswas et al. 2019).

Meatballs as emulsion products are usually contain fillers in the form of tapioca flour. Tapioca flour in the processing of culled duck meatballs can be substituted with edamame flour as filler. The filler substitution in processed meat products as an innovation to optimize local resources (Syam et al. 2019). Edamame has been used as filler in the processing of sausages. Edamame was a Japanese variety of green soybeans and large pods (Suryaningsih 2013) and contains bioactive components (Aliyah \& Setiawati 2018; Widiyawati \& Susindra 2018). Edamame production in Indonesia was widely developed in Jember. Chemical compositions of edamame flour consist of $3.22 \%$ moisture, $40.02 \%$ protein, $18.43 \%$ fat, $34.65 \%$ carbohydrate, and $3.78 \%$ ash. Edamame flour based on its chemical compositions can be used as a filler and binder with high protein and carbohydrate contents. The chemical quality of meatballs was one of the important parameters in determining nutritional value of meatballs. This study aimed to determine the effect of edamame flour filler substitution on the chemical quality of the culled duck meatballs. Results of this study were expected to become information about the use of edamame flour as filler in the processing of culled duck meatballs.

\section{MATERIALS AND METHODS}

\section{Edamame flour processing}

Edamame skin was peeled. Edamame seeds were crushed, and then dried at $60^{\circ} \mathrm{C}$ for 24 hours and then ground until smooth then sieved using a filter with a size of 60 mesh. Filtered edamame flour was used as filler for the processing of culled duck meatballs. The scheme of edamame flour processing was presented at Figure 1.

\section{Meatball processing}

The culled duck meatball formulation in this study was made based on a modification of Prayitno et al. (2019). The boneless duck meat was cut into small pieces and then ground using meat grinder, followed by the addition of salt, pepper, monosodium glutamate (MSG), sodium tripolyphosphate (STPP), garlic, onion, albumen, tapioca flour, edamame flour according to treatment, and ice then ground until all mixed. The meatball dough was formed balls boiled in boiling water for 10 minutes then cooled for 15 minutes. The

Table 1. The formulation of culled duck meatballs substituted with edamame flour filler

\begin{tabular}{lccccc}
\hline \hline \multirow{2}{*}{ Ingredients } & \multicolumn{3}{c}{ Treatments } \\
\cline { 2 - 6 } & $\mathrm{P} 0$ & $\mathrm{P} 1$ & $\mathrm{P} 2$ & $\mathrm{P} 3$ & $\mathrm{P} 4$ \\
\hline Culled duck meat (\%) & 60 & 60 & 60 & 60 & 60 \\
Tapioca flour (\%) & 15 & 14.25 & 13.5 & 12.75 & 12 \\
Edamame flour (\%) & 0 & 3.75 & 7,5 & 11.25 & 15 \\
Albumen (\%) & 10 & 10 & 10 & 10 & 10 \\
Garlic (\%) & 2.5 & 2.5 & 2.5 & 2.5 & 2.5 \\
Onion (\%) & 1 & 1 & 1 & 1 & 1 \\
Salt (\%) & 1.5 & 1.5 & 1.5 & 1.5 & 1.5 \\
Pepper (\%) & 1 & 1 & 1 & 1 & 1 \\
Monosodium glutamate (\%) & 1 & 1 & 1 & 1 & 1 \\
Sodium tripolyphosphate (\%) & 1 & 1 & 1 & 1 \\
Ice (\%) & 7 & 7 & 7 & 7 & 1 \\
\hline & 100 & 100 & 100 & 100 & 100 \\
\hline T0tal (\%) & & & & 7 \\
\hline
\end{tabular}

P0 (0\%), P1 (5\%), P2 (10\%), P3 (15\%), and P4 (20\%) substitution edamame flour from total filler 
cooked meatballs then tested on chemical quality. The scheme of culled duck meatball processing was presented at Figure 2. The formulation of substitution with edamame flour filler was presented at Table 1 .

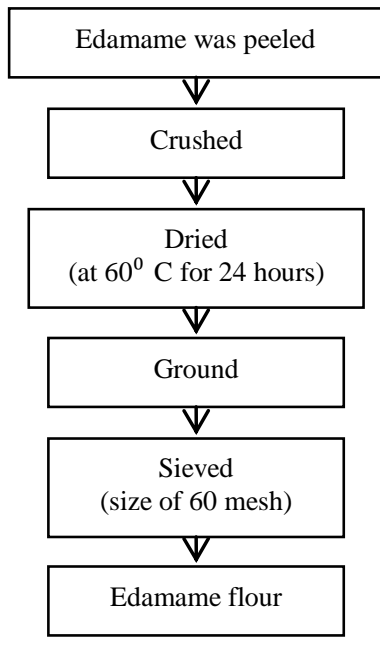

Figure 1. The scheme of edamame flour processing

\section{Chemical quality analysis}

The chemical composition of culled duck meatballs substituted with edamame flour filleranalyzed following standard AOAC methods (AOAC 2019). The proximate measurements were moisture, protein, fat, fiber, and ash contents.

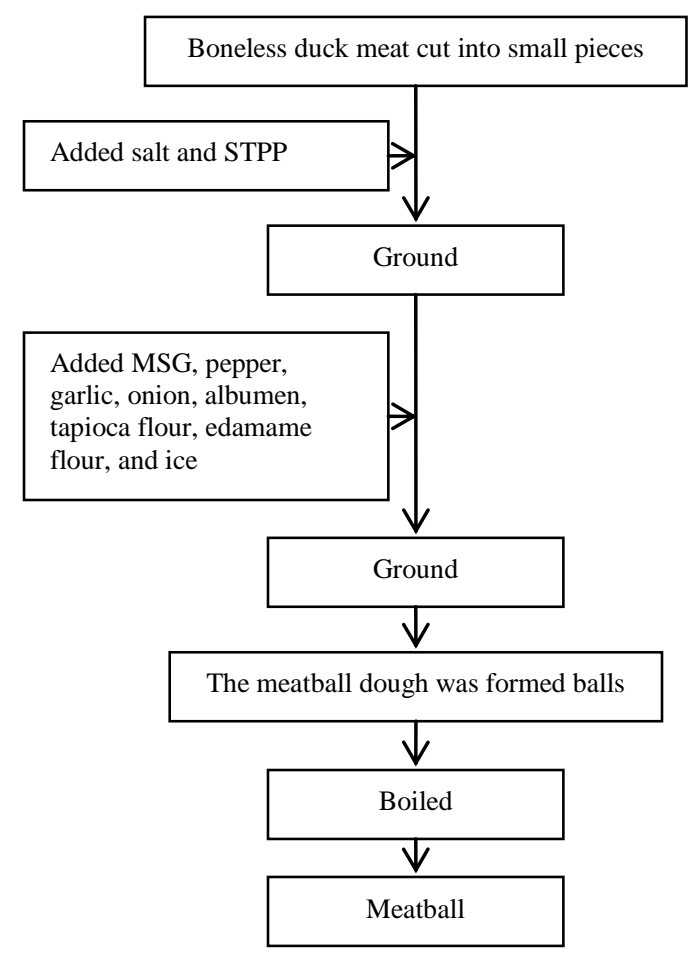

Figure 2. The scheme of meatball processing

\section{Statistical analysis}

The data were analyzed by analysis of variance using completely randomized design and if there was significantly different $(\mathrm{P}<0.01)$, then tested further by the Duncan's New Multiple Range Test.

\section{RESULTS AND DISCUSSION}

Chemical quality of meatballs was one of the important parameters that become the standard in determining the nutritional value of meatballs. The chemical quality was presented in Table 2 .

\section{Moisture content}

Results showed that the culled duck meatball substituted with edamame flour filler had a highly significant effect $(\mathrm{P}<0.01)$ on the moisture content of the meatball. The moisture content ranged from 45.05$46.93 \%$. This result was lower than that of beef meatball of 73.70-74.61\% (Malini et al. 2016). Edamame flour substitutions were increased from $5 \%$ to $20 \%$, followed by significantly decreased in water content of the meatballs. This was because edamame flour has lower water content than tapioca flour. Edamame flour has a moisture content of $3.22 \%$, while tapioca flour has a moisture content of $8.36 \%$ (Safitri et al. 2017). The moisture content from his study was in agreement with the standard because it was below the maximum limit of the meatball moisture content of $70 \%$ (SNI 2014). This result was lower than that resulted by Anggraini et al. (2017), the meatball water content was 65.40-67.26\%.

\section{Protein content}

Results showed that the substitution of filler had a highly significant effect $(\mathrm{P}<0.01)$ on the protein content of the meatball. The meatball protein levels ranged from $10.61-16.13 \%$. The protein content of this meatball was higher than the protein content of beef meatball of 11.22-12.10\% (Malini et al. 2016). As the substitutions of filler increased from $5 \%$ to $20 \%$, protein content of the meatballs increased significantly. This was because edamame flour has higher protein content than tapioca flour. Edamame flour has a protein content of $40.02 \%$, while tapioca flour has a protein content of $3.05 \%$ (Safitri et al. 2017). The protein content of the meatball was in agreement with the standard because it was above the minimum limit of the meatball protein content of $8 \%$ (SNI 2014). This result was higher than that resulted by Nurkhoeriyati et al. (2012), the meatball protein was 6.58-7.67\%. 
Table 2. The chemical composition of culled duck meatballs substituted with edamame flour filler

\begin{tabular}{lccccc}
\hline \hline \multirow{2}{*}{ Variables } & \multicolumn{5}{c}{ Treatments } \\
\cline { 2 - 6 } & P0 & P1 & P2 & P3 & P4 \\
\hline Moisture (\%) & $46.93^{\mathrm{a}}$ & $46.43^{\mathrm{b}}$ & $46.09^{\mathrm{c}}$ & $45.58^{\mathrm{d}}$ & $45.05^{\mathrm{e}}$ \\
Protein (\%) & $10.61^{\mathrm{a}}$ & $11.68^{\mathrm{b}}$ & $13.11^{\mathrm{c}}$ & $14.60^{\mathrm{d}}$ & $16.13^{\mathrm{e}}$ \\
Fat (\%) & $17.16^{\mathrm{a}}$ & $17.81^{\mathrm{b}}$ & $18.51^{\mathrm{c}}$ & $19.18^{\mathrm{d}}$ & $19.86^{\mathrm{e}}$ \\
Fiber (\%) & $0.11^{\mathrm{a}}$ & $0.57^{\mathrm{b}}$ & $1.11^{\mathrm{c}}$ & $1.55^{\mathrm{d}}$ & $2.24^{\mathrm{e}}$ \\
Ash (\%) & $0.84^{\mathrm{a}}$ & $0.93^{\mathrm{b}}$ & $1.03^{\mathrm{c}}$ & $1.14^{\mathrm{d}}$ & $1.19^{\mathrm{e}}$ \\
\hline abcde
\end{tabular}

$\overline{\text { abcde }}$ Means in the same row with different lettersuperscriptswere significantly different $(\mathrm{P}<0.01)$

\section{Fat content}

Results showed that the culled duck meatball substituted with edamame flour filler had a highly significant effect $(\mathrm{P}<0.01)$ on the fat content of the meatball. The fat content ranged from 17.16-19.86\%. The fat content from this study was higher than the fat content of beef meatball of 1.59-2.27\% (Malini et al. 2016). As Edamame flour substitutions increased from $5 \%$ to $20 \%$, the fat content significantly increased. This was because edamame flour has higher fat content than tapioca flour. Edamame flour has a fat content of $18.43 \%$, while tapioca flour has a fat content of $0.12 \%$ (Safitri et al. 2017). The fat content exceeded the standard because it was above the maximum limit of the meatball fat content of $10 \%$ (SNI 2014). This result was higher than that of Lestari et al (2015), namely 12.21$28.21 \%$. Consuming high-fat content foods might increase obesity and risk of degenerative diseases (Freeman et al. 2014).

\section{Fiber content}

The substitution of edamame flour filler had a highly significant effect $(\mathrm{P}<0.01)$ on the level of meatball fiber. The meatball fiber levels ranged from $0.11-2.24 \%$. This result was almost the same as the beef meatball fiber content of $0.13-4.86 \%$ ( $\mathrm{Hu} \& \mathrm{Yu} 2015$ ). The increased edamame flour substitutions from $5 \%$ to $20 \%$, followed by significantly increased in fiber content of the meatballs. This was because edamame flour has higher fiber content than tapioca flour. Edamame flour has a fiber content of $3.27 \%$ (Widiyawati\& Susindra 2018), while tapioca flour has a fiber content of $2.18 \%$ (Charoenkul et al. 2011). The levels of culled duck meatball substituted with edamame flour filler were following previous studies which stated that the levels of meatball fiber ranged from 0.26-2.90\% (Kurniawan et al. 2012).

\section{Ash content}

The substitution of edamame flour filler had a very significant effect $(\mathrm{P}<0.01)$ on ash content of the meatball. It was ranged from 0.84-1.19\%. The ash content of culled duck meatball was higher than the ash content of beef meatball of 2.28- 2.35\% (Malini et al. 2016). As the substitution increased from 5\% to $20 \%$, the ash content significantly increased. This was because edamame flour has higher ash content than tapioca flour. Edamame flour has a protein content of $3.78 \%$, while tapioca flour has a protein content of $2.39 \%$ (Safitri et al. 2017). The content of duck meatball ash substituted with edamame flour filler is in accordance with the standard because it is below the maximum limit of the meatball ash content of 3\% (SNI 2014).

\section{CONCLUSION}

The results showed that the substitution of edamame flour filler starting from the level of 5\% was significantly affect water content, protein, fat, fiber, and ash of culled duck meatballs. Edamame flour can be used as a filler substitution up to $20 \%$ level by giving a good effect on increasing the meatball protein content, but also might have negative impact with increasing the fat content of the meatballs.

\section{REFERENCES}

Aliyah S, Setiawati SI. 2018. Perbandingan formula enteral rendah lemak berbasis tepung edamame dengan formula komersial rendah lemak. Media Gizi Indones. 13:1-11.

Anggraini PN, Susanti S, Bintoro VP. 2017. Karakteristik fisikokimia dan organoleptik bakso itik dengan tepung porang sebagai pengenyal. J Teknol Pangan. 3:155-160.

[AOAC] Association of Official Analytical Collaboration International. 2019. Official Methods of Analysis of the Association of Analytical Chemists. $21^{\text {th }}$ ed. Washington DC: Association of Official Analytical Chemist.

Biswas S, Banerjee R, Bhattacharyya D, Patra G, Das AK, Das SK. 2019. Technological investigation into duck meat and its products - a potential alternative to chicken. Worlds Poult Sci J. 75:609-620. 
Chakim L, Dwiloka B, Kusrahayu. 2013. Tingkat kekenyalan, daya mengikat air, kadar, dan kesukaan pada bakso daging sapi dengan substitusi jantung sapi. Anim Agric J. 2:97-104.

Charoenkul N, Uttapap D, Pathipanawat W, Takeda Y. 2011. Physicochemical characteristics of starches and flours from cassava varieties having different cooked root textures. LWT - Food Sci Technol. 44:1774-1781.

Freeman LR, Haley-Zitlin V, Rosenberger DS, Granholm AC. 2014. Damaging effects of a high-fat diet to the brain and cognition: A review of proposed mechanisms. Nutr Neurosci. 17:241-251.

Hafid H, Nuraini, Inderawati. 2015. Potensi produksi karkas itik lokal afkir yang berasal dari peternakan rakyat di Sulawesi Tenggara. In: Pros Semin Nas Teknol Peternak dan Vet 2015. Malang: Badan Penelitian dan Pengembangan Pertanian Kementerian Pertanian; p. 443-447.

Haslia F, Adzitey F, Huda N, Ali GRR. 2015. Effect of temperature on the growth and survival of pathogens in duck and quail meatballs. J Life Sci Biomed. 5:48-52.

He J, Zheng H, Pan D, Liu T, Sun Y, Cao J, Wu Z, Zeng X. 2018. Effects of aging on fat deposition and meat quality in Sheldrake duck. Poult Sci. 97:2005-2010.

Hu G, Yu W. 2015. Effect of hemicellulose from rice bran on low fat meatballs chemical and functional properties. Food Chem. 186:239-243.

Huda N, Putra AA, Ahmad R. 2011. Proximate and physicochemical properties of Peking and Muscovy duck breasts and thighs for further processing. J Food, Agric Environ. 9:82-88.

Kurniawan AB, Al-Baarri AN, Kusrahayu. 2012. Kadar serat kasar, daya ikat air, dan rendemen bakso ayam dengan penambahan keraginan. J Apl Teknol Pangan. 1:23-27.

Kusmayadi A, Sundari RS. 2019. Program diversifikasi dan uji organoleptik produk olahan daging dan telur itik. EDIMAS J Pengabdi Kpd Masy. 10:1-6.

Lestari FEP, Jakaria, Rukmiasih. 2015. Sensori dan karakteristik asam lemak daging itik Cihateup, Alabio dan silangannya. J Sains Terap. 5:17-25.

Lestarini IN, Anggarawati N, Nuhriawangsa AMP, Dewanti R. 2015. Manfaat penambahan tepung kunyit (Curcuma domestica $\mathrm{Val}$ ) dan tepung jahe (Zingiber officinale) terhadap kualitas bakso itik afkir dengan lama penyimpanan yang berbeda. Bul Peternak. 39:9-16.

Malini DR, Ariefb II, Nuraini H. 2016. Utilization of durian seed flour as filler ingredient of meatball. Media Peternak. 39:161-167.

Murti S, Suharyanto, Kaharudin D. 2013. Pengaruh pemberian kunyit (Curcuma domestica) terhadap beberapa kualitas fisik dan organoleptik bakso daging itik. J Sain Peternak Indones. 8:16-24.
Nurkhoeriyati T, Huda N, Ahmad R. 2012. Physicochemical properties and sensory analysis of duck meatballs containing duck meat surimi-like material during frozen storage. J Food Sci. 71:S91-S98.

Prayitno AH, Suryanto E, Rusman. 2016. Pengaruh fortifikasi nanopartikel kalsium laktat kerabang telur terhadap sifat kimia dan fisik bakso ayam. Bul Peternak. 40:40-47.

Prayitno AH, Suryanto E, Rusman, Setiyono, Jamhari, Utami R. 2019. Pengaruh fortifikasi kalsium dan nanopartikel kalsium laktat kerabang telur terhadap sifat sensoris bakso ayam. In: Pros Semin Nas Teknol Peternak dan Vet. Bogor (Indones): Pusat Penelitian dan Pengembangan Peternakan; p. 725-732.

Purba M, Laconi EB, Ketaren PP, Wijaya CH, Hardjosworo PS. 2010. Kualitas sensori dan komposisi asam lemak daging itik lokal jantan dengan suplementasi santoquin, vitamin $\mathrm{E}$ dan $\mathrm{C}$ dalam ransum. JITV. 15:47-54.

Putra AA, Huda N, Ahmad R. 2011. Changes during the processing of duck meatballs using different fillers after the preheating and heating process. Int $\mathrm{J}$ Poult Sci. 10:62-70.

Qiao Y, Huang J, Chen Y, Chen H, Zhao L, Huang M, Zhou G. 2017. Meat quality, fatty acid composition and sensory evaluation of Cherry Valley, Spent Layer and Crossbred ducks. Anim Sci J. 88:156-165.

Safitri IO, Rusmarilin H, Ridwansyah. 2017. Pengaruh perbandingan tepung talas, tapioka, dengan tepung mocaf dan persentase terhadap mutu keripik tempe inovasi. J Rekayasa Pangan Pertan. 5:290-300.

Smith DP, Northcutt JK, Qudsieh RI, Parisi MA. 2015. Effect of sex, bird size and marination onon duck breast meat quality. J Appl Poult Res. 24:401-407.

[SNI] Standar Nasional Indonesia. 2014. Bakso Daging. Jakarta (Indones): Badan Standardisasi Nasional.

Suryaningsih W. 2013. Karakteristik sosis ayam dengan penambahan edamame sebagai bahan substitusi. J Ilm Inov. 13:296-305.

Syam J, Irmawaty, Kasim K. 2019. Substitusi tepung sukun (Artocarpus altilis [Parkinson.] Fosber) sebagai fillerbinder dalam bakso daging sapi. J Ilmu Ind Peternak. 5:12-20.

Utami DP, Pudjomartatmo, Nuhriawangsa AMP. 2011. Manfaat bromelin dari ekstrak buah nanas (Ananas comosus L. Merr) dan waktu pemasakan untukmeningkatkan kualitas daging itik afkir. Sains Peternak. 9:82-87.

Widiyawati A, Susindra Y. 2018. Utilization of edamame soybean (Glycine $\max (\mathrm{L})$ Merril) as modified of enteral formula high calories. IOP Conf Ser Earth Enveronmental Sci. 207. 